Laporan Penelitian

\title{
Efektivitas salin hipertonik terhadap waktu transpor mukosiliar dan skor gejala hidung penderita rinitis alergi
}

\author{
Woro Safitri, Dwi Reno Pawarti, Titiek Hidayati Ahadiah \\ Departemen Ilmu Kesehatan Telinga Hidung Tenggorok - Bedah Kepala Leher \\ Fakultas Kedokteran Universitas Airlangga/ \\ Rumah Sakit Umum Daerah Dr. Soetomo \\ Surabaya
}

\begin{abstract}
ABSTRAK
Latar belakang: Rinitis alergi (RA) adalah suatu penyakit inflamasi mukosa hidung yang diperantara oleh imunoglobulin E (IgE), setelah mukosa hidung terpapar alergen. Tujuan: Mengidentifikasi efektivitas cuci hidung salin hipertonik terhadap waktu transpor mukosiliar dan skor gejala hidung total (SGHT) pada penderita RA. Metode: Penelitian dilaksanakan pada bulan Juli hingga Desember 2016 di Poli Telinga Hidung Tenggorok - Bedah Kepala Leher Rumah Sakit Dr. Soetomo Surabaya. Uji klinis acak terkontrol pada 2 kelompok dengan desain control group in clinical trial. Pengambilan sampel dilakukan secara consecutive sampling. Uji korelasi yang digunakan adalah uji t berpasangan dan uji Wilcoxon. Hasil: Didapatkan sampel 42 penderita, yaitu 21 penderita pada kelompok loratadin, serta 21 penderita pada kelompok loratadin dan cuci hidung salin hipertonik. Didapatkan rerata penurunan transpor mukosiliar kelompok loratadin dan cuci hidung salin hipertonik lebih bermakna daripada kelompok loratadin $(\mathrm{p}=0,001)$. Penurunan transpor mukosiliar kelompok loratadin didapatkan rerata $-2,30(\mathrm{SD}=2,77)$, kelompok loratadin dan cuci hidung salin hipertonik didapatkan rerata $-6,27(\mathrm{SD}=3,91)$. Penurunan SGHT kelompok loratadin didapatkan rerata $-2,48(\mathrm{SD}=1,72)$, sedangkan kelompok loratadin dan cuci hidung salin hipertonik didapatkan rerata $-4,3(\mathrm{SD}=1,20)$. Kesimpulan: Penambahan cuci hidung salin hipertonik pada terapi loratadin lebih efektif dibandingkan terapi tunggal loratadin dalam menurunkan transpor mukosiliar dan SGHT pada penderita RA.
\end{abstract}

Kata kunci: Loratadin, cuci hidung salin hipertonik, transpor mukosiliar, skor gejala hidung total, rinitis alergi

\begin{abstract}
Background: Allergic rhinitis (AR) is a nasal mucous membrane inflamatory which mediated by Imunoglobulin E (IgE) after allergen exposure in nasal mucosa. Purpose: To identify the effectiveness of nasal hypertonic saline irrigation on reduction of mucociliary transport time (MCTT) and total nasal symptom score (TNSS) in AR patients. Methods: The was conducted from July until December 2016 in Oto Rhino Laryngology - Head and Neck Surgery of Dr. Soetomo Hospital Surabaya. The study was randomized controlled clinical trials on two groups, with the control group in clinical trial design. Paired t and Wilcoxon test was used as the correlation test. Results: There was 42 patients, 21 patients in loratadine group, and 21 patients in loratadine with hypertonic nasal saline group. The average of mucociliary transport time decrease of loratadine with hypertonic nasal saline group was more significant than loratadine group $(p=0.001)$. The mean of decreasing mucociliary transport time in loratadine group was -2.30 (SD=2.77) and loratadine with hypertonic nasal saline group was -6.27 (SD=3.91). The mean of decreasing TNSS in loratadin group was -2.48 $(S D=1.72)$, and loratadin with hypertonic nasal saline group was $-4.3(S D=1.20)$. Conclusions: The addition of hypertonic nasal saline in loratadine was more effective, compared to monotherapy of loratadine in decreasing mucociliary transport time and TNSS in patient with AR.
\end{abstract}

Keywords: Loratadine, hypertonic nasal saline, mucociliary transport, total nasal symptom score, allergic rhinitis 
Alamat korespondensi: Dr. Woro Safitri, Departemen Ilmu Kesehatan Telinga Hidung Tenggorok Fakultas Kedokteran Universitas Airlangga/Rumah Sakit Umum Daerah Dr. Soetomo Surabaya, Jl. Mayjen Prof. Dr. Moestopo 6-8, Surabaya. Email: safitriworo@gmail.com.

\section{PENDAHULUAN}

Rinitis alergi (RA) adalah suatu penyakit inflamasi mukosa hidung yang diperantarai oleh Imunoglobulin E (Ig E), setelah terjadi paparan alergen pada mukosa hidung. Rinitis alergi merupakan penyakit yang mendapat perhatian para ahli karena berdampak negatif terhadap produktivitas dan kualitas hidup penderita sehingga menjadi masalah kesehatan dunia. ${ }^{1}$ Penderita RA mengalami peningkatan waktu transpor mukosiliar hidung karena terjadi pembengkakan, kerusakan membran plasma sel bersilia, sehingga mengganggu gerakan silia yang dapat mempengaruhi gejala klinik. ${ }^{2,3}$ Beratnya gejala RA dapat dinilai berdasarkan skor gejala hidung total (SGHT). ${ }^{4,5}$

Salah satu terapi RA lini pertama yang direkomendasikan oleh Allergic Rhinitis and its Impact on Asthma (ARIA) 2008 adalah loratadin. ${ }^{4}$ Loratadin adalah terapi RA yang pada beberapa kasus kurang optimal, dengan angka keberhasilan terapi loratadin pada penderita RA adalah $80 \%{ }^{6}$ Tingginya insiden RA yang berdampak pada kualitas hidup mendorong para ahli untuk mengembangkan terapi baru selain loratadin, yaitu dengan cuci hidung salin hipertonik. ${ }^{7,8}$ Sampai saat ini masih belum diketahui jelas efektivitas penambahan cuci hidung salin hipertonik terhadap penurunan waktu transpor mukosiliar dan SGHT pada penderita RA yang mendapat terapi loratadin di Rumah Sakit Umum Daerah (RSUD) Dr. Soetomo Surabaya.

Prevalensi RA pada dekade terakhir ini cenderung meningkat mencapai $10-25 \%$ populasi penduduk dunia. Lebih dari 500 juta orang menderita penyakit ini, yang merupakan salah satu penyebab terbanyak seseorang mengunjungi dokter umum maupun dokter spesialis Telinga Hidung Tenggorok -
Bedah Kepala Leher (THT-KL), ${ }^{4,9,10}$ Angka kunjungan penderita RA di Unit Rawat Jalan (URJ) THT-KL RSUD Dr. Soetomo Surabaya cukup tinggi dan cenderung mengalami peningkatan dalam beberapa tahun terakhir. Berdasarkan data berbasis komputer dari Instalasi Teknologi Informasi (ITI) RSUD Dr. Soetomo Surabaya dilaporkan kasus RA pada tahun 2012 sebanyak 951, tahun 2013 sebanyak 1018.

Terapi standar di Unit URJ THT-KL Divisi Alergi antara lain menggunakan antihistamin loratadin. Loratadin merupakan antihistamin generasi kedua, yaitu derivat klor dari azatadin, tanpa efek sedatif maupun antikolinergik pada dosis biasa. Efek anti alerginya berdasarkan perannya sebagai antagonis reseptor $\mathrm{H} 1$ dan daya menghambat sintesis berbagai mediator inflamasi. ${ }^{11}$ Loratadin berkerja dengan cara inhibisi reseptor histamin, sitokin, serta ekspresi ICAM-1, sehingga menghambat adhesi eosinofil pada pembuluh darah. ${ }^{12,13}$

Sistem transpor mukosiliar merupakan sistem yang bekerja secara aktif dan simultan, tergantung pada gerakan silia untuk mendorong gumpalan mukus dan benda asing yang terperangkap masuk saat menghirup udara melalui sistem transportasi di saluran pernapasan atas dan bawah. Transpor mukosiliar disebut sebagai lini pertama dan dasar dalam mekanisme pertahanan tubuh yang bekerja secara aktif menjaga agar saluran pernapasan atas selalu bersih dan sehat dengan membawa partikel debu, bakteri, virus, alergen, toksin yang tertangkap pada lapisan mukus ke arah nasofaring. ${ }^{14,15}$ Secara teoritis, salin hipertonik dapat mengurangi edema mukosa dengan cara difusi karena osmolaritasnya, sehingga diharapkan dapat meningkatkan daya pembersih mukosiliar. ${ }^{16}$ Waktu transpor mukosiliar pada mukosa 
hidung yang diberi cuci hidung dengan salin hipertonik lebih baik daripada salin isotonik. ${ }^{7}$ Pada penelitian sebelumnya, yang membandingkan penggunaan salin hipertonik dengan salin isotonik didapatkan hasil bahwa salin hipertonik lebih baik dibanding dengan salin isotonik dalam hal menurunkan waktu transpor mukosiliar. ${ }^{17}$

Penelitian ini bertujuan untuk mengidentifikasi efek penambahan salin hipertonik pada terapi loratadin, dibandingkan terapi tunggal loratadin yang dinilai berdasarkan waktu transpor mukosiliar dan skor gejala hidung total penderita RA.

\section{METODE}

Penelitian dilaksanakan pada bulan Juli hingga Desember 2016 di URJ THT-KL Divisi Alergi Imunologi RSUD Dr. Soetomo Surabaya. Jenis penelitian ini adalah uji klinis acak terkontrol pada 2 kelompok. Pengambilan sampel dilakukan secara consecutive sampling, didapatkan sampel sebanyak 42. Semua sampel penelitian menjalani pemeriksaan skin prick test, penghitungan waktu transpor mukosiliar, dan skor gejala hidung total. Sampel penelitian adalah penderita RA yang datang berobat ke URJ THT-KL Divisi Alergi Imunologi RSUD Dr. Soetomo Surabaya dan memenuhi kriteria penelitian.

Kriteria inklusi yaitu berusia 21-60 tahun, bebas obat-obatan anti alergi: AH (1 minggu), kortikosteroid sistemik (4 minggu), kortikosteroid topikal (2 minggu), dekongestan topikal (1 minggu), antikolinergik, dan kromolin (selama 2 minggu), bersedia ikut dalam penelitian dan menandatangani surat persetujuan mengikuti penelitian serta persetujuan tindakan. Kriteria eksklusi yaitu adanya infeksi saluran napas akut, sinusitis paranasal akut dan kronis, rinitis medikamentosa, kelainan hidung seperti tumor, polip nasi, septum deviasi berat, serta dalam kondisi hamil atau menyusui, riwayat alergi obat loratadin dan riwayat mempunyai penyakit degeneratif.

Tahapan penelitian dimulai dengan diagnosis penderita RA berdasarkan anamnesis, pemeriksaan fisik, dan skin prick test. Penderita yang bersedia menandatangani surat persetujuan, pengukuran waktu transpor mukosiliar, dan penilaian SGHT, kemudian dilakukan pencatatan ke dalam lembar pengumpul data oleh peneliti. Pengukuran waktu transpor mukosiliar hidung dilakukan dengan tes sakarin yang diberi zat pewarna methylen blue (sebelum dan sesudah terapi). Hasil penilaian dicatat pada status penelitian. Pengolahan dan analisis data dengan tingkat kemaknaan (p) sebesar 5\% atau 0,05 . Uji statistik yang digunakan untuk mengetahui perbandingan efek terapi antara loratadin dan kombinasi loratadin dengan cuci hidung memakai salin hipertonik terhadap waktu transpor mukosiliar hidung dan SGHT ialah menggunakan uji $\mathrm{t}$ berpasangan. Uji statistik yang digunakan untuk mengetahui perbandingan antara praterapi dan pascaterapi loratadin terhadap SGHT menggunakan uji Wilcoxon.

\section{HASIL}

Berdasarkan Chi square test, distribusi umur dan jenis kelamin terhadap pemberian loratadin dan kombinasi loratadin dengan cuci hidung memakai salin hipertonik didapatkan nilai secara berurutan, $p=0,52$ dan $p=0,07$. Hal ini menunjukkan bahwa pada distribusi umur antara kedua kelompok berbeda tidak bermakna $(\mathrm{p}>0,05)($ tabel 1).

Pada penelitian ini, sebanyak 8 penderita tidak bekerja yaitu mahasiswa $(38,10 \%)$ pada tiap kelompok diberi terapi. Jenis pekerjaan yang paling sedikit adalah dokter dan salesman masing-masing 1 penderita (4,76\%), yang terdapat pada kelompok dengan terapi loratadin. Terdapat perbedaan sebaran klasifikasi RA antara kedua kelompok. Pada penelitian ini tidak melibatkan penderita 
Tabel 1. Hubungan karakteristik sampel penelitian dengan kelompok perlakuan

\begin{tabular}{|c|c|c|c|c|c|}
\hline \multicolumn{2}{|c|}{ Karakteristik sampel } & \multirow{2}{*}{$\begin{array}{r}\text { Loratadin } \\
12(57,14 \%)\end{array}$} & \multirow{2}{*}{$\begin{array}{c}\begin{array}{c}\text { Loratadin dengan cuci } \\
\text { hidung salin hipertonik }\end{array} \\
13(61,91 \%)\end{array}$} & \multirow{2}{*}{$\frac{\text { Total }}{25(59,52)}$} & \multirow[t]{2}{*}{$\mathbf{p}$} \\
\hline \multirow{4}{*}{ Distribusi umur } & $21-30$ & & & & \\
\hline & $31-40$ & $4(19,05 \%)$ & $6(28,57 \%)$ & $10(23,81)$ & \multirow{3}{*}{0,52} \\
\hline & $41-50$ & $4(19,05 \%)$ & $1(4,76 \%)$ & $5(11,91)$ & \\
\hline & $51-60$ & $1(4,76 \%)$ & $1(4,76 \%)$ & $2(4,76)$ & \\
\hline \multirow{4}{*}{ Jenis kelamin } & Laki-laki & $3(14,29 \%)$ & $18(85,71 \%)$ & $11(26,19)$ & \multirow[b]{2}{*}{0,07} \\
\hline & Perempuan & $18(85,71 \%)$ & $3(14,29 \%)$ & $31(73,81)$ & \\
\hline & $\begin{array}{l}\text { Tidak bekerja } \\
\text { (mahasiswa) }\end{array}$ & $8(38,10 \%)$ & $8(38,10 \%)$ & $16(38,10)$ & \multirow{8}{*}{-} \\
\hline & Tidak bekerja (IRT) & $2(9,53 \%)$ & $2(9,53 \%)$ & $4(9,52)$ & \\
\hline \multirow{6}{*}{ Jenis pekerjaan } & Cleaning service & $3(14,30 \%)$ & $2(9,53 \%)$ & $5(11,91)$ & \\
\hline & Guru & $2(9,53 \%)$ & - & $2(4,76)$ & \\
\hline & Pegawai kantor & $2(9,53 \%)$ & $3(14,30 \%)$ & $5(11,91)$ & \\
\hline & Salesman & $1(4,76 \%)$ & $2(9,53 \%)$ & $3(7,14)$ & \\
\hline & Dokter & $1(4,76 \%)$ & $2(9,53 \%)$ & $3(7,14)$ & \\
\hline & Perawat & $2(9,53 \%)$ & $2(9,53 \%)$ & $4(9,52)$ & \\
\hline \multirow{3}{*}{ Klasifikasi RA } & Intermiten ringan & $2(9,52 \%)$ & $2(9,52 \%)$ & $4(9.52)$ & \multirow{3}{*}{-} \\
\hline & $\begin{array}{l}\text { Intermiten sedang } \\
\text { berat }\end{array}$ & $13(61,91 \%)$ & $5(23,81 \%)$ & $18(42,86)$ & \\
\hline & Persisten ringan & $6(28,57 \%)$ & $14(66,67)$ & $20(47,62)$ & \\
\hline
\end{tabular}

dengan diagnosis RA persisten sedang berat karena tidak termasuk dalam kriteria inklusi (tabel 1).

Uji statistik terhadap waktu transpor mukosiliar praterapi dan pascaterapi dengan uji t 2 sampel berpasangan didapatkan nilai $\mathrm{p}=0,001$. Nilai tersebut menunjukkan waktu transpor mukosiliar kedua kelompok pra dan pascaterapi adalah berbeda bermakna $(\mathrm{p}<0,05)$. Uji statistik terhadap perbedaan $(\Delta)$ waktu transpor mukosiliar menggunakan uji t 2 sampel bebas didapatkan nilai $\mathrm{p}=0,001$. Nilai tersebut menunjukkan waktu transpor mukosiliar kedua kelompok berbeda bermakna $(\mathrm{p}<0,05)$ (tabel 2).

Uji statistik terhadap SGHT pra dan pascaterapi dengan uji Wilcoxon didapatkan nilai $\mathrm{p}=0,001$. Nilai tersebut menunjukkan SGHT kedua kelompok pra dan pascaterapi adalah berbeda bermakna $(p<0,05)$

Uji statistik terhadap perbedaan $(\Delta)$ SGHT menggunakan uji Wilcoxon didapatkan nilai $\mathrm{p}=0,001$. Nilai tersebut menunjukkan penurunan SGHT pada kedua kelompok berbeda bermakna $(p<0,05)$.
Efek samping mengantuk dilaporkan oleh penderita pada kelompok loratadin sebanyak 4 penderita (19,05\%). Efek samping hidung kering hanya didapatkan pada kelompok loratadin dan cuci hidung salin hipertonik sebanyak 2 penderita $(9,53 \%)$. Selain itu, efek samping hidung terasa panas terdapat pada kelompok loratadin dan cuci hidung salin hipertonik sebanyak 1 penderita (4,76\%). Penderita yang tidak didapatkan efek samping sebanyak masing-masing 17 penderita $(80,95 \%)$ pada kedua kelompok.

\section{DISKUSI}

Hasil penelitian menunjukkan distribusi umur antara kedua kelompok perlakuan tidak ada perbedaan $(p=0,52)$. Kelompok umur terbanyak pada penelitian ini adalah 21-30 tahun yaitu 25 penderita $(59,52 \%)$ dan kelompok umur paling sedikit adalah 51-60 tahun sebanyak 2 penderita (4,76\%). Rerata umur pada kelompok loratadin 32,14 dan kelompok loratadin dengan cuci hidung salin hipertonik adalah 30,24 tahun. Albu 
Tabel 2. Perbandingan penurunan transpor mukosiliar pra dan pascaterapi

\begin{tabular}{|c|c|c|c|c|c|c|c|c|}
\hline \multirow{3}{*}{ Kelompok } & \multirow{3}{*}{$\mathbf{n}$} & \multicolumn{4}{|c|}{ Waktu transpor mukosiliar } & \multirow{2}{*}{\multicolumn{2}{|c|}{$\Delta$ Transpor mukosiliar }} & \multirow{3}{*}{ p } \\
\hline & & \multicolumn{2}{|c|}{ Praterapi } & \multicolumn{2}{|c|}{ Pascaterapi } & & & \\
\hline & & rerata & $\mathrm{SD}$ & rerata & $\mathrm{SD}$ & rerata & SD & \\
\hline Loratadin & 21 & 11,44 & 4,91 & 9,13 & 4,33 & $-2,30$ & 2,77 & 0,001 \\
\hline $\begin{array}{l}\text { Loratadin dan } \\
\text { cuci hidung salin } \\
\text { hipertonik }\end{array}$ & 21 & 12,52 & 4,55 & 6,25 & 2,00 & $-6,27$ & 3,91 & 0,001 \\
\hline
\end{tabular}

Tabel 3. Perbandingan penurunan SGHT praterapi dan pascaterapi

\begin{tabular}{|c|c|c|c|c|c|c|c|c|}
\hline \multirow{3}{*}{ Kelompok } & \multirow{3}{*}{$\mathbf{n}$} & \multicolumn{4}{|c|}{ SGHT } & \multicolumn{2}{|c|}{$\Delta$ SGHT } & \multirow{3}{*}{ p } \\
\hline & & \multicolumn{2}{|c|}{ Praterapi } & \multicolumn{2}{|c|}{ Pascaterapi } & \multirow[b]{2}{*}{ rerata } & \multirow[b]{2}{*}{$\mathrm{SD}$} & \\
\hline & & rerata & SD & rerata & $\mathrm{SD}$ & & & \\
\hline Loratadin & 21 & 5,52 & 1,83 & 3,05 & 1,24 & $-2,48$ & 1,72 & 0,001 \\
\hline $\begin{array}{l}\text { Loratadin dan } \\
\text { cuci hidung salin } \\
\text { hipertonik }\end{array}$ & 21 & 6,62 & 1,50 & 2,24 & 1,22 & $-4,38$ & 1,20 & 0,001 \\
\hline
\end{tabular}

Tabel 4. Efek samping pascaterapi

\begin{tabular}{lccc}
\hline Efek samping & Loratadin & $\begin{array}{c}\text { Loratadin dengan } \\
\text { cuci hidung salin } \\
\text { hipertonik }\end{array}$ & Total \\
\cline { 2 - 4 } & $\mathrm{n}(\%)$ & $\mathrm{n}(\%)$ & $(\%)$ \\
\hline Mengantuk & $4(19,05)$ & $1(4,76)$ & $5(11,91)$ \\
Hidung kering & $0(0,0)$ & $2(9,53)$ & $2(4,76)$ \\
Hidung panas & $0(0,0)$ & $1(4,76)$ & $1(2,38)$ \\
Tidak ada & $17(80,95)$ & $17(80,95)$ & $34(80,95)$ \\
\hline Total $(\%)$ & $21(100)$ & $21(100)$ & $42(100)$ \\
\hline
\end{tabular}

\& Baschir ${ }^{18}$ pada penelitiannya, didapatkan hasil yaitu kelompok studi dengan rerata umur 31,42 dan kelompok kontrol 33,56. Al Suleimani \& Walker ${ }^{19}$ telah melakukan penelitian di Amerika dengan prevalensi RA yang bervariasi yaitu kelompok umur $\leq 17$ tahun (32\%), $18-44$ tahun $(43 \%)$, 45-64 tahun (17\%) dan $\geq 65$ tahun (8\%). Hayati ${ }^{5}$ dalam penelitiannya juga melaporkan kelompok usia penderita RA terbanyak yaitu usia 21-30 tahun sebesar 37,5\%.

Pada penelitian ini, distribusi jenis kelamin antara kelompok loratadin dan kelompok loratadin dengan cuci hidung salin hipertonik terdapat hasil tidak ada perbedaan $(\mathrm{p}=0,07)$. Jenis kelamin perempuan sebanyak 31 penderita $(73,81 \%)$ dan laki- laki sebanyak 11 penderita (26,19\%). Hasil penelitian ini sesuai dengan penelitian lain yang menunjukkan bahwa pendertita dengan jenis kelamin perempuan lebih banyak dari laki-laki. ${ }^{20}$ Insiden RA pada masa reproduksi ditemukan lebih tinggi pada perempuan. Hormon estrogen pada perempuan mempunyai efek meningkatkan inflamasi, sebaliknya hormon testosteron pada laki-laki mempunyai efek menurunkan inflamasi. Rinitis alergi dapat ditemukan pada semua umur tetapi alergen inhalan sebagai penyebab terbanyak didapatkan pada dewasa muda. ${ }^{20}$

Distribusi jenis pekerjaan terbanyak adalah tidak bekerja (mahasiswa) yaitu 16 penderita $(38,10 \%)$, tidak bekerja (ibu 
rumah tangga) dan perawat masing-masing sebanyak 4 penderita $(9,52 \%)$, cleaning service dan guru masing-masing 5 penderita $(11,91 \%)$, serta sales man dan dokter masingmasing 3 penderita $(7,14 \%)$. Hasil penelitian ini dapat disebabkan oleh karena profesi tersebut lebih mudah terpapar alergen dari lingkungan sekolah ataupun lingkungan, dengan tempat belajar dan bekerja yang berdebu dengan ventilasi ruangan yang kurang baik. Hasil penelitian ini sesuai dengan penelitian Rahmawati, Punagi \& Savitri, ${ }^{21}$ yang mendapatkan bahwa sebagian besar penderita RA berprofesi mahasiswa $(35 \%)$.

Klasifikasi RA menurut ARIA-WHO berdasarkan waktu atau lama dan berat ringannya gejala. Penelitian ini melibatkan penderita dengan diagnosis intermiten ringan, intermiten sedang berat dan persisten ringan. Didapatkan RA terbanyak adalah persisten ringan sebanyak 20 penderita $(47,62 \%)$, intermiten sedang berat sebanyak 18 penderita $(42,86 \%)$, serta intermiten ringan 4 penderita $(9,52 \%)$. Rambe et $\mathrm{al}^{22}$ meneliti jumlah kasus terbanyak menurut klasifikasi ARIA/WHO yaitu RA persisten sedang berat sebanyak $36,6 \%$, RA intermiten sedang berat dan persisten ringan masing-masing $23,3 \%$ dan yang paling sedikit adalah RA intermiten ringan yaitu $16,7 \%$. Penelitian Asha'ari et $\mathrm{al}^{23}$ terhadap 142 pasien RA, didapatkan $10 \%$ pasien RA intermiten ringan, 21,1\% RA intermiten sedang berat, 20\% RA persisten ringan, dan 48,9\% RA persisten sedang berat. Manifestasi derajat keparahan RA berpengaruh terhadap kualitas hidup penderita RA. Inflamasi yang terjadi dalam waktu yang lama dan terus-menerus akan mengakibatkan peningkatan prevalensi alergi. Diduga akibat berbagai faktor internal dan eksternal memengaruhi kekambuhan dan keparahan RA, atau telah timbul komplikasi. ${ }^{24}$

Rerata waktu transpor mukosiliar praterapi pada kelompok loratadin 11,44 dan pada kelompok loratadin dan cuci hidung salin hipertonik adalah 12,52 dengan nilai $\mathrm{p}=0,001$. Rerata waktu transpor mukosiliar pascaterapi pada kelompok loratadin adalah 9,13 dan kelompok loratadin dan salin hipertonik adalah 6,25. Uji statistik penelitian ini terhadap penurunan waktu transpor mukosiliar menggunakan uji t berpasangan didapatkan hasil rerata penurunan berbeda bermakna dengan $p=0,001$. Disimpulkan bahwa penambahan salin hipertonik pada RA yang mendapat terapi loratadin lebih efektif menurunkan waktu transpor mukosiliar.

Pada penelitian ini, kelompok loratadin mendapatkan perlakuan terapi loratadin $10 \mathrm{mg}$ selama 14 hari. Didapatkan hasil penurunan waktu transpor mukosiliar tidak sebaik pada kelompok yang mendapatkan terapi loratadin dengan cuci hidung salin hipertonik. Pada RA terjadi pelepasan mediator dan sitokin seperti histamin, leukotrien, prostaglandin, PAF, dan akumulasi sel inflamasi pada penderita RA, sehingga menyebabkan mukosa hidung mengalami edema yang akan menyebabkan rinore. Disfungsi mukosiliar menyebabkan terjadinya stagnansi mukus sehingga mengganggu sistem mukosiliar rongga hidung. ${ }^{1}$

Loratadin mempunyai efek menghambat kerja sel inflamasi dalam melepaskan mediator seperti sitokin, kemokin dan molekul adhesi yang merupakan komponen pengatur respon inflamasi akibat paparan alergen. Loratadin juga menghambat pelepasan histamin oleh basofil dengan cara stabilisasi membran, inhibisi influks $\mathrm{Ca}^{2+}$ transmembran, sehingga menyebabkan $\mathrm{Ca}^{2+}$ meningkat. ${ }^{25}$ Efek anti inflamasi pada loratadin tersebut bisa memperbaiki fungsi mukosiliar pada hidung. ${ }^{1}$

Penderita RA mengalami peningkatan waktu tempuh transpor mukosiliar karena terjadi pembengkakan, kerusakan membran plasma sel bersilia serta mukus yang masuk di antara silia dan diduga sebagai penyebab kegagalan gerakan silia., ${ }^{2,3}$ Efisiensi cuci hidung dengan salin hipertonik sebagai terapi RA terjadi karena menyebabkan keadaan 
hiperosmolar di saluran pernafasan, sehingga terjadi pelepasan kalsium dan prostaglandin E2 dari intraseluler. Sifat dari salin hipertonik di antaranya sebagai antiseptik, mengurangi mediator inflamasi, mengurangi edema pada mukosa, mengurangi sekresi musin, meningkatkan transpor mukosiliar dengan meningkatkan frekuensi gerakan silia. ${ }^{26}$

Pengukuran waktu tranpor mukosiliar merupakan salah satu cara untuk mengetahui fungsi mukosa hidung setelah diberikan semprot hidung salin hipertonik. ${ }^{27}$ Li et $\mathrm{al}^{28}$ melakukan penelitian pada 26 anak berusia 8-15 tahun dengan riwayat RA. Penderita dilakukan evaluasi perubahan kecepatan transpor mukosiliar setelah mendapat terapi semprot hidung sehari dua kali selama 12 minggu. Didapatkan penurunan hasil pengukuran transpor mukosiliar sesudah terapi sebanyak $37 \%$.

Cuci hidung dengan salin hipertonik bisa menurunkan $\mathrm{C} 4$ dan leukotrin pada penderita RA. Efek utama dari cuci hidung hidung adalah mampu melembabkan mukosa, hidrasi, pengangkatan debris dan krusta untuk mencegah infeksi sekunder serta merangsang penyembuhan mukosa. Cuci hidung ini mampu mengangkat debris dan mukus yang berlebihan, sehingga proses pembersihan mukosiliar menjadi lebih baik dengan cara meningkatkan frekuensi cilliary beat. $^{27,29}$ Kandungan salin hipertonik ini mampu mengurangi edema melalui difusi osmolaritas. Sifat asam yang berada di lapisan perisiliar (sol layer) dan lapisan superfisial atau lapisan mukus (gel layer) ini mampu dikurangi viskositasnya oleh salin hipertonik yang bersifat basa, sehingga bisa memperbaiki sistem transpor mukosiliar. ${ }^{29}$

Didapatkan rerata SGHT praterapi pada kelompok loratadin 5,52 dan kelompok loratadin dengan salin hipertonik adalah 6,62. Uji statistik penelitian ini terhadap $\Delta$ SGHT menggunakan uji t berpasangan, didapatkan hasil rerata penurunan SGHT berbeda bermakna dengan $p=0,001$. Disimpulkan bahwa penambahan salin hipertonik pada RA yang mendapat terapi loratadin lebih efektif menurunkan SGHT. Perubahan SGHT ini sesuai dengan hasil penelitian Raptopoulou, seperti yang dikutip oleh Assanasen \& Naclerio, ${ }^{25}$ melaporkan bahwa pasien yang diterapi dengan loratadin $10 \mathrm{mg}$ menunjukkan pengurangan skor gejala hidung secara bermakna dibanding plasebo. Penelitian ini menunjukkan hasil yang sama dengan penelitian komparatif oleh Lutsky seperti dikutip Buck. ${ }^{11}$ Penelitian tersebut dilakukan pada 96 penderita RA, didapatkan penurunan bermakna gejala hidung dan bukan hidung setelah mendapat terapi loratadin dengan respons terapi sebesar $82 \%$.

Aktivasi sel mast di mukosa hidung melepaskan histamin. Mediator ini menyebabkan kelenjar mukosa dan sel goblet mengalami hipersekresi serta permeabilitas kapiler meningkat. Saraf kolinergik bagian eferen akan mengaktivasi kelenjar submukosa dan interaksi ini menyebabkan pilek. Mediator inflamasi dan neurogenik berkontribusi untuk menimbulkan eksudasi plasma dan vasodilatasi yang menyebabkan edema mukosa hidung. Penderita RA mengalami peningkatan SGHT, karena gejala RA terdiri atas gejala hidung yaitu pilek, buntu hidung, bersin dan gatal hidung serta gejala di luar hidung yaitu mata berair, gatal pada mata, telinga, palatum dan tenggorok. ${ }^{30}$ Sifat dari salin hipertonik antara lain diduga sebagai antiseptik dan mengurangi mediator inflamasi, sehingga bisa menurunkan SGHT. ${ }^{26}$

Efek samping terbanyak yang dilaporkan pada penelitian ini adalah rasa mengantuk pada 5 penderita $(11,91 \%)$. Efek samping paling sedikit adalah hidung terasa panas 1 penderita $(2,38 \%)$, sedangkan tidak ada keluhan sebanyak 34 penderita $(80,95 \%)$. Papsin $^{7}$ mengatakan bahwa kecepatan transpor mukosiliar pada larutan garam hipertonik lebih baik daripada larutan garam isotonik. Talbot et al ${ }^{17}$ juga melakukan penelitian pada 21 orang dengan rata-rata usia 25-45 tahun 
untuk membandingkan penggunaan larutan hipertonik dengan larutan isotonik. Hasil penelitian tersebut didapatkan larutan garam hipertonik lebih baik daripada larutan garam isotonik dalam hal meningkatkan kecepatan transpor mukosiliar.

Dapat disimpulkan bahwa penambahan cuci hidung salin hipertonik pada terapi loratadin dibandingkan terapi tunggal loratadin lebih efektif dalam menurunkan transpor mukosiliar dan SGHT pada penderita RA.

\section{DAFTAR PUSTAKA}

1. Lehman JM, Blaiss MS. Pharmacotherapy of allergic rhinitis. In: Pawankar, Holgate ST, Rosenwasser, eds. Allergy Frontiers: Therapy and Prevention, USA : Springer, 2010; p. 19 - 36.

2. Shimizu T. Mucus, goblet cell, submucusal gland. In: T. Metin Önerci. Nasal physiology and pathophysiology of nasal disorders. Berlin: Springer. 2013; p. 1-11.

3. Jorissen M, Jaspers M. Cilia, ciliary movement, and mucociliary transport. In: T. Metin Önerci. Nasal physiology and pathophysiology of nasal disorders. Berlin: Springer. 2013; p.15-25.

4. Brozek JL, Bousquet J, Baena-Cagnani CE, Bonini S, Canonina GW, Casale TB, et al. Allergic rhinitis and its impact on asthma (ARIA) guidelines: 2010 revision. J Allergy Clin Immunol. 2010; 126: 466-76.

5. Hayati R. Perubahan skor gejala klinis dan kualitas hidup pasca terapi loratadin pada penderira rinitis alergi. Departemen Ilmu Kesehatan Telinga Hidung Tenggorok Bedah Kepala dan Leher Fakultas Kedokteran Unair/RSUD Dr. Soetomo, Surabaya, 2010; hal 1-3.

6. Sarumpaet RD. Perbandingan efektifitas antara loratadine dan chlorpheniramine maleat terhadap kualitas hidup penderita rinitis alergi perenial. Laporan penelitian. Tesis. Semarang: Pascasarjana Universitas Diponegoro. 2010.
7. Papsin B, McTavish A. Saline nasal irrigation: its role as an adjunct treatment. Can Fam Physician. 2003; 49:168-72.

8. Keomjampa BK, Nguyen MH, Ryan MW. Effect of buffered saline solution on nasal mucociliary clearance and nasal airway patency. Otolaryngol Head Neck Surg. 2004; 131(5):679-82.

9. Suprihati. Penatalaksanaan rinitis alergi sesuai WHO-ARIA. Konas PERHATI-KL. $2003 ; 2-13$

10. Pawarti DR. Diagnosis rinitis alergi. Dalam: Wiyadi HMS, Herawati S, Harmadji S, Pawarti DR, ed. Recent advances and update management of allergic rhinitisrhinosinusitis. Pendidikan Kedokteran Berkelanjutan VI Ilmu Kesehatan Telinga Hidung Tenggorok-Bedah Kepala dan Leher. Surabaya: Departemen / SMF Ilmu Kesehatan THT-KL FK UNAIR-RSU Dr. Soetomo. 2009; hal 1-15.

11. Buck ML. Loratadine and desloratadine use in children. Pediatric Pharmacotherapy. 2011; 17(5):1-4.

12. Ciprandi G, Marseglia GL, Klersy C, Tosca MA. Relationships between allergic inflammation and nasal airflow in children with persistent allergic rhinitis due to mite sensitization. Allergy. 2005; 60:957-60.

13. Koreck AI, Csoma Z, Bodai L, Ignacz F, Kenderessy AS, Kadocsa E, et al. Rhinophototherapy: a new therapeutic tool for the management of allergic rhinitis. $\mathrm{J}$ Allergy Clin Immunol. 2005; 115(3): 541-7.

14. Ballenger JJ. Anatomy and physiology of the nose and paranasal sinuses. In: Ballenger JJ, Snow JB, eds. Ballenger's otorhinolaryngology head and neck surgery, 16th edition., Philadelphia : Williams \& Wilkins. 2003; p.547-60.

15. Kirtsreesakul V, Somjareonwattana P, Ruttanaphol S. The correlation between nasal symptom and mucociliary clearance in allergic rhinitis. Laryngoscope. 2009; 119(8):1458-62. 
16. Rabago D, Barrett B, Marchand L, Maberry R, Mundt M. Qualitative aspects of nasal irrigation use by patients with chronic sinus disease in a multimethod study. Ann Fam Med. 2006; 4(4):295-301.

17. TalbotAR, Herr TM, Parsons DS. Mucociliary clearance and buffered hypertonic saline solution. Laryngoscope. 1997; 107(4): 5003.

18. Albu S, Baschir S. Intranasal phototherapy versus azelastine in the treatment of seasonal allergic rhinitis. Auris Nasus Larynx. 2013. 40(5):447-51.

19. Al Suleimani YM, Walker MJ. Allergic rhinitis and its pharmacology. Pharmacol Ther. 2007; 114(3):233-60.

20. Osman M, Hansell AL, Simpson CR, Hollowell J, Helms PJ. Gender-specific presentations for asthma, allergic rhinitis and eczema in primary care. Prim Care Respir J. 2007; 16(1):28-35.

21. Rahmawati, Punagi AQ, Savitri E. Hubungan antara gejala rinitis, reaktivitas tes cukit kulit, dan kadar imunoglobulin E pada pasien rinitis alergi. Indonesian J Med Sci. 2008; 1:1-9.

22. Rambe AYM, Fadhlia, Munir D, Haryuna TSH, Eyanoer PC. Hubungan rinitis alergi dan disfungsi tuba Eustachius dengan menggunakan timpanometri. Oto Rhino. 2013; 43(1):80-9.

23. Asha'ari ZA, Yusuf S, Ismail R, Che Hussin CM. Clinical features of allergic rhinitis and skin prick test analysis based on the ARIA classification: A preliminary study in Malaysia. Ann Acad Med Singapore. 2010; 39(8):619-24.
24. Karya IW, Aziz K, Rahardjo SP, Djufri NI. Pengaruh rinitis alergi (ARIA WHO 2001) terhadap gangguan fungsi ventilasi tuba Eustachius. CDK. 2007; 35: 405-10.

25. Assanasen P, Naclerio RM. Antiallergic anti-inflamatory effects of $\mathrm{H} 1$-antihistamines in humans. Clin Allergy Immunol. 2002; 17:101-39.

26. Šlapak I, Skoupá J, Strnad P, Horník P. Efficacy of isotonic nasal wash (seawater) in the treatment and prevention of rhinitis in children. Arch Otolaryngol Head Neck Surg. 2008; 134(1):67-74.

27. Hermelingmeier KE, Weber RK, Hellmich $\mathrm{M}$, Heubach CP, Mosges R. Nasal irrigation as an adjunctive treatment in allergic rhinitis: a systematic review and meta-analysis. Am J Rhinol Allergy. 2012; 26(5):119-25.

28. Li H, Sha Q, Zuo K, Jiang H, Cheng L, Shi $\mathrm{J}$, et al. Nasal saline irrigation facilitates control of allergic rhinitis by topical steroid in children. ORL J Otorhinolaryngol Relat Spec. 2009; 71(1):50-5.

29. Taccariello M, Parikh A, Darby Y, Scadding G. Nasal douching as valuable adjunct in the management of chronic rhinosinisitis. Rhinology. 1999; 37(1):29-32.

30. Bousquet J, Khaltaev N, Cruz AA, Denburg J, Fokkens WJ, Togias A, et al. Allergic rhinitis and its impact on asthma (ARIA). 2008. Allergy 63 (Suppl.86):8-160. 